\title{
Sajarah Cina
}

\section{A nineteenth-century apology in Javanese}

\author{
WiLlem VAN DER MOLEN
}

\begin{abstract}
The sometimes precarious position of the Chinese in Indonesia has a long history. The (most probably) nineteenth-century author, Apdul Mutalip, advocated a more balanced view by pointing out some fundamental contributions the Chinese had made to the welfare of the Javanese; he also demonstrates that their presence in Java has a basis in law. Although seems like a poem in Javanese metre, his Sajarah Cina, written in Javanese, is remarkable not only for its subject matter but also for the way the material is presented, in a rhetoric unknown to exist in Javanese literature by most scholars.
\end{abstract}

KEYWORDS

Chinese in Java; Javanese historiography; manuscripts.

\section{INTRODUCTION}

Sajarah Cina is the name of a short poem in Javanese of unknown date about the Chinese in Java. It does not deal with Sino-Javanese history in general; rather, it concentrates on one particular aspect, the negative image of the Chinese in Javanese society. This it sets out to redress.

The author of the Sajarah Cina calls himself Apdul Mutalip. I could not find any information about this author, nor do I know of any other works written by him. The Sajarah Cina perhaps never reached print. The only copy I know of is a handwritten copy of three pages - two sheets of paper - kept in the Library of Leiden University (KITLV Or 409). The outward appearance of the poem points to a Javanese readership as the intended audience: it is written in Javanese, in Javanese script, in a traditional type of metre called macapat. The simple layout of the manuscript, with a text filling the paper to the edges, written by a trained hand, but without any attempt to produce a

WILLEM VAN DER MOLEN taught Javanese and Old Javanese at Universiteit Leiden for thirty years, from 1979 onwards. In 2008 he joined the KITLV (Royal Institute of Southeast Asian and Carribean Studies) in Leiden, where he is a researcher. Since 2010 he is also adjunct-professor of Old Javanese and Philology at Universitas Indonesia in Depok. Besides these regular occupations he is frequently involved in summer schools on Old Javanese. Recently, he published a history of Javanese literature (in Russian).Willem van der Molen can be contacted at: molen@kitlv.nl. 
fine copy, suggests a copy for private use of this particular copy (as does the underscoring of names). See the photographs of the manuscript accompanying this article (Appendix 1).

The text bears no date, but cannot be later than 1890, the year in which the owner of the manuscript died (that is, if he did own the manuscript and if it was not added to his estate at a later date). The present copy is on machinemade paper and is therefore later than the 1840s. Words in the text such as Gupermèn (unlike Kumpeni which was used prior to the nineteenth century) point to the nineteenth century as the time at which the text was created.

The former owner of the manuscript was a Peranakan Chinese named Ko Ho Sing (Jana 1825 - Yogyakarta 1890), ${ }^{1}$ a rich merchant of Yogyakarta. Little is known about him. The Sajarah Cina gives us an idea of the kinds of things in which Ko Ho Sing was interested.

Pigeaud's catalogue of Javanese manuscripts in the Netherlands has a note on the importance of the historical information given by the Sajarah Cina:

A Javanese poem in kina $\square \square$ i verse (33 stanzas) on the life of Tumĕygun Mĕrta Guna of Lasĕm is a particularly interesting item of the addenda. He was a Chinese trader originally called Cik Go Ing; he served Sina Wijaya, a former Regent of Lasĕm, also of Chinese origin, and was made tumĕngun in his place by the Sultan of Mataram as a reward for his services in the war with Surabaya. Many Regents of Lasĕm, Tuban, Kudus, Blora and Boja Nagara are said to be descendants of Mĕrta Guna, and allied by marriage with Chinese families (Pigeaud 1980: 244-245).

Actually, the poem contains thirty-four stanzas. The Javanese text has Mĕrtiguna, not Mĕrtaguna. Kinanți is one of the traditional verse forms which as a whole are called macapat. Given the scarcity of information about the Chinese in Java (especially from the earlier period), any piece of documentation elucidating their history is welcome. However, in contrast to Pigeaud I see the Sajarah Cina not primarily as a source of historical information but as an apology in which the historical information supplied is one of the arguments for the defence. In other words, the historical information is made subordinate to the rhetorical argument, as we shall see below. It is this defence and the rhetoric used in it I wish to address here. Before I do so, I shall first give an outline of the contents of the text.

\section{SumMary OF THE SAJARAH CINA}

The contents of the Sajarah Cina can be summarized as follows:

Stanza 1. Opening.

Stanzas 2-12. Javanese society is a prosperous society characterized by an unlimited abundance of food and material goods. Everything is within easy reach, thanks to the numerous ubiquitous Chinese shopkeepers. Forgoing any desire is unnecessary: people short of cash are helped out by the many Chinese pawn shops and moneylenders, on reasonable terms. One should be 
aware, however, that most of the money collected by the Chinese flows into the government coffers in the form of taxes. Misappropriations at auctions are a rare occurrence; it is clear that the great majority of the Chinese want nothing more than to carry on their businesses.

Stanzas 13-22. A long time ago, in the days of Sultan Agung, a Chinese merchant called Cik Gong Té was shipwrecked while on his way to Java to trade. Having lost everything but his life, he entered the service of the sultan, converted to Islam and was appointed an official in the coastal district of Lasem. After he had settled there, relatives of Cik Gong Té began to immigrate to the area of Lasem and neighbouring Rembang. Cik Gong Té died and was succeeded by one of his sons.

Stanzas 23-33. Next, Chinese and Javanese alike obeyed Sultan Agung's call to war against Surabaya. As a reward for his bravery during the war, one Mertiguna, of Chinese descent and related to the Cik Gong Té family, was appointed Regent of Lasem. His descendants by marriage became connected with various regents in and beyond the Pasisir. It is a pity that the fostering of special ties between the Chinese and the Javanese reigning elite is given less priority nowadays.

Stanza 34. Closing stanza.

\section{STRAINED RELATIONS}

Religion and politics but above all commerce have inspired the Chinese to call in at Java since times immemorial, but evidence of permanent settlement is relatively late. A traveller's report from the middle of the fifteenth century mentions Chinese among the inhabitants of Java. The Muslim who founded the Islamic state of Demak in the last quarter of the fifteenth century might have been a Chinese. The Port of Gresik was established in the fourteenth century by Chinese (Ricklefs 2008: 6, 38, 41).

More information is available after AD 1600. Emigration was triggered from the southern provinces of China in particular by the economic hardship caused by the exhaustion of the soil. Farmers fled to Java where they had better chances to make a living in agriculture, trade and the local Javanese and Dutch administration (especially farms or leases). A certain degree of assimilation did take place between the new settlers and the Javanese, but was not at any time complete. This might be explained by the fact that the immigrants were all male; the usual pattern was that they married local wives or descendants of mixed marriages. Consequently, differences in language and custom were preserved intact by the constant influx of new immigrants.

The Dutch began farming out taxes in the first decades of their presence in Java, in the early seventeenth century. Charges were levied on a variety of goods and activities, including opium, spirits, gambling and abattoirs. The leases were sold at auction, mainly to Chinese, who would then try to extract as much money as possible from them. At the same time, they also became the moneylenders of the Javanese. The system which allowed for extortion and financial bondage landed not a few Javanese in penury, a misery often 
aggravated by the physical effects of opium. The government was reluctant to intervene in view of the profit it made from the leases; this system would last until the beginning of the twentieth century (Bruineman 1946).

Although the Dutch were behind it, it was the visible actions and claims of the Chinese to which the Javanese were directly exposed on a daily basis. Small wonder then that it was the Chinese rather than the Dutch who became the target of their frustration. What could the Sajarah Cina do about it?

\section{VIEWPOINT OF THE SAJARAH CINA}

The Sajarah Cina is a carefully constructed apology devised to eradicate negative ideas and appease bad feelings. How does it intimate that these ideas and feelings do not reflect the real situation? With several possibilities at his disposal, the author decides to suggest a different point of view as his line of defence. He does not deny or refute the facts as people see them but offers a different interpretation. Charges are narrowed down to number, greed and dissociation. However, nowhere are these mentioned explicitly: the tone of the poem is positive; any negative association is avoided.

The problem of number is tackled by looking at what nobody would deny to be an ideal state of affairs, prosperity, and how it this can be achieved. Prosperity, as the poem makes clear, implies two things: a state of abundance of food and goods (including luxury goods like opium and spirits) and access to them. Access has to be taken into consideration because there is no prosperity if the former cannot be enjoyed. Access depends on two conditions: a robust infrastructure and solvency (the commodities have to be brought to the people, and they have to be able to buy them).

Now the role of the Chinese can be explained. They are important because they are ubiquitous, in great numbers, shops (including opium-dens) are to be found everywhere, offering an overwhelming supply of necessities; anything felt to be missing can be ordered without too many problems. It is thanks to this infrastructure that prosperity is within the reach of everyone. Nobody is excluded from enjoying it because, like the shops, money-brokers and pawnshops are also everywhere, helping out should one happen to be short of cash.

Greed manifests itself through excessive interest; holding a monopoly is the condition that makes it possible. The Sajarah Cina asserts that there are no high rates. It shows why high rates would indeed be unlikely. If the Chinese lend money, it is because they are helpful; they cannot stand the thought that someone might have nothing to eat. A misunderstanding could have risen from the Chinese habit of prospering in silence, so that their lofty intentions might not have been recognized. The Chinese do not claim any monopoly; on the contrary, one might say that they set an example to be followed. There is hardly any trickery at auctions. As for the taxes on trades and services, the reader is reminded that these, though Chinese-levied, flow to the Dutch. If making money from money would seem to be a problem, in view of the Islamic prohibition on interest, this is indeed irrefutable. But, so the author points 
out, was it not the Arabs who contrived a way to get around the prohibition? Nor are the Javanese themselves famous for their strict observance of the Islamic law.

Dissociation, the third charge mentioned above, is divided into being alien and lacking commitment. In the Sajarah Cina these charges are countered by legitimacy and a shared history.

As for legitimacy, the Chinese not only happen to have lived in Java for ages, but their presence has a legal foundation according to the text. The procedure involved meets all the requirements to validate it: the contract is datable, it was made voluntarily, by identifiable parties, who were vested with the authority to draw up a contract, and no legal objections were encountered in drawing it up; finally, it was duly implemented. In concrete terms: the contract was drawn up during the reign of Sultan Agung (r. 1613-1646) between Sultan Agung, the ruler of Mataram, and the Chinese Cik Gong Té, the highest authority on board a ship which sailed for Java (he was the juragan 'captain', who owned the ship and the cargo). The ship was wrecked off the Javanese coast, with Cik Gong Té as the sole survivor. He decided to offer to enter the sultan's service and was accepted.

Next, a couple of things happened which followed from the contract and strengthened it. Cik Gong Té, now officially a servant (dasih) of the sultan, decided to become a Muslim. He was then appointed (not specified in what function) to the district of Lasem, and he was given a Javanese name (Singaleksana). A Chinese community began to grow in Lasem and neighbouring Rembang, swelled by Cik Gong Té's descendants and by relatives who arrived from China to live with him in Java.

Further developments show that these people did not live in isolation but formed a part of Javanese society and shared in the trials and tribulations of Javanese society. They joined Sultan Agung in the war against Surabaya (defeated in 1625), and Cik Gong Té's descendants continued to serve the rulers of Mataram and would rise to the rank of bupati, marrying into Javanese bupati families and for a considerable time provided bupatis in a vast area outside Lasem.

\section{RHETORICAL ASPECT}

For centuries authors of texts (and orators) who want their audience to accept some truth have exploited the rules of rhetoric, the art of persuading. In the West, rhetoric as a profession was established and developed by the ancient Greeks and Romans. In order to put his message across to his readers, the author of the Sajarah Cina draws extensively on a rhetoric that is reminiscent of what the Greeks and the Romans invented and perfected. Is this because there is something universal about rhetoric, or did European rhetoric - perhaps through India - reach Java? It seems that rhetoric as it was known in Europe was not much developed in India (or in China, for that matter); see Kennedy 
1998. ${ }^{2}$ I do not know of any Javanese texts on rhetoric but there must have been a Javanese tradition. An early example - again, strikingly close to western rhetoric - is Sita's letter in the Old Javanese Ramayana (late ninth century), in which she tries to convince her husband that she has remained faithful to him; see Van der Molen 2003.

Classical rhetoric educates the aspiring author in how to build strong arguments, how to find the best way of presenting them, and, last but not least, how to make his audience favourably disposed towards his argumentation. The author of the Sajarah Cina deals with all three.

\section{Arguments}

After having decided which hypothesis to defend, the first step in any argument should be to make sure that the author and his audience are talking about the same thing. This is what the author of the Sajarah Cina does when he explains the three key concepts of prosperity, greed and being a stranger. In rhetoric this is called applying the common topic of definition (Corbett and Connors 1999: 85).

Next, the author wants to make it plausible that the Chinese do contribute to prosperity, are not greedy and are not foreign. The arguments adduced for this purpose in the Sajarah Cina take on the form of the enthymeme, which is the usual form in rhetoric: the Chinese boost prosperity because they are numerous; they are not greedy because they are helpful; and they are a part of society in a legal and tried-and-tested way. In rhetorical terms what the author is doing here is applying the common topics of antecedent and consequence, of contraries, and of cause and effect, respectively; his way of reasoning is deductive. Each of the arguments is in turn based on similar sub-arguments.

What has just been said discusses arguments based on reason; ideally, an author could leave it at that. However, passion and will play a role in human nature as much as does intellect. The ancient rhetoricians therefore added two more means of persuasion: the ethical appeal - the persuasive value of the speaker's or writer's character -, and the appeal to the emotions of the audience (Corbett and Connors 1999: 71-72, 77). Both means are also applied in the Sajarah Cina. An emotional appeal is made, for example, when the history of the Chinese is presented as something familiar (tepang, Line 34e), as something the poet's friends (pawong mintra) should know about (dé wrin, Line $34 \mathrm{~d}$ ). The urge to be grateful (sunga trima kasih, Line $7 \mathrm{~b}$ ) is yet another example. The author makes an ethical appeal when he tells us that he is at home in the material and therefore knows what he is talking about. He does so indirectly, by informing us that he has studied the subject for a long time (wus lami ngong udi, Line 1d). Another example is the information about who he is: his name (Apdul Mutalip, Line 34f) identifies him as Javanese and Muslim, in other words, as "one of us".

2 Kennedy does not look into Arabic or Persian traditions; Southeast Asia is also outside his scope. The "rhetorical" universals observed by him are linguistic universals (see his final chapter, Kennedy 1998: 215-230). 
Contingent to the ethical appeal is consistency. Being knowledgeable, for example, should not only be intimated but should also be apparent in the discussion which follows (Braet [N.d.]: 51). In the case of the Sajarah Cina, the survey of historical developments shows precisely that. However, there is a problem. The first Chinese are said by the text to have arrived in the days of Sultan Agung but we know they had already appeared a long time before that. How are we to reconcile this seeming contradiction? Possible solutions might be that the author is talking about only a limited community, living in the area of Lasem in particular or that, as the legal basis of the Chinese is the focus of discussion, he omits all that is not connected.

\section{Arrangement}

The above is the rhetoric blueprint with which the author of the Sajarah Cina skilfully constructs his arguments. He shows that he is no less skilful in arranging and presenting them. An introduction according to the handbooks should - evidently - introduce a subject to the audience; it should also arouse the interest of the audience and make it receptive. Arousing the interest can be done, for example, by showing that the subject is important or interesting; by convincing the audience one is qualified to speak on some subject it will be made receptive (Corbett and Connors 1999: 260-264).

The introduction of the Sajarah Cina takes up Stanza 1:

Feeling a strong desire

I wish to write a poem

and make its contents known.

Because for a long time I have made special study

of the early history of the Chinese

who were the first to come to Java.

The conventional wording of the first three lines, on reflection and inner urge, ring a familiar bell; as such it helps to make the audience receptive. The subject of the fourth line, the poet's willingness to share his experience, represents undeniable proof of his unselfishness - another means to enhance receptivity. It also implies authority, albeit wrapped in a cloak of modesty: the poet has studied for a long time (so he is an expert). Without any further digressions, he mentions the actual topic in the two concluding lines. History is a sure means of drawing the attention of the Javanese. They are fond of history, as one can see from their literature: more has been written about history in Javanese than about anything else. Once the author has caught the attention, he does not have to add more; he should just commence his story, and this is what he does.

So all the ingredients of an introduction are there: introducing the subject, arousing interest, and creating receptivity. The inner arrangement of the introduction is likewise the fruit of rhetorical effort: claiming authority without common ground has little prospect; therefore, the introduction begins by preparing the mind of the audience; claiming authority before 
mentioning the topic of discussion enhances the attention (through suspense); all requirements having been fulfilled, the author can go on to the main part of his argumentation.

One might wonder why the author's revealing his identity as a Javanese Muslim is relegated to the last line of the final stanza, Line 34f. Given its function of underlining his authority, would not the introduction have been the proper place to have done this? Probably not: the author's arguments can be judged to be well constructed, but how does one know that he is speaking the truth? The moment this doubt makes itself felt most acutely is at the end, after the audience has heard all the arguments. This is the moment the author's identity should be thrown in, to prevent the audience from stopping short of the point to which he wants to bring it, the acceptance of his views. Such a deviation from the standard order of rhetoric is not a mistake - it is an acknowledged procedure. Rhetorical skill also implies the ability to tune in with the situation. After all, the purpose of the rules is "to adapt discourse to its end" (Braet [N.d.]: 76). Once more, the author of the Sajarah Cina shows that he has a thorough command of the art.

\section{Style}

Style is about diction and composition (Corbett and Connors 1999: 341). It is another means of "arousing the appropriate emotional response in the audience and [...] establishing the proper ethical image" (Corbett and Connors 1999: 337). This is precisely how it is used in the Sajarah Cina.

The style of the Sajarah Cina could be described as a matter-of-fact. The language is plain and simple (in spite of a couple of words which I was unable to interpret). There is hardly any embellishment. We find no figures of speech or puns, for example. Stanza 1 contains two of the few examples of alliteration (see lines bc and ef):

dénira mayun murwani
medhar surasaning gita
prawitané para Cina
kang prataming tanah Jawi

dénira mayun murwani prawitané para Cina kang prataming tanah Jawi
I wish to write a poem and make its contents known of the early history of the Chinese who were the first to come to Java

By their capacity to draw the attention of the audience, such devices strengthen the function of an introduction so, if used at all in a text, it is here that one would expect them.

On the other hand, embellishment is not completely avoided. So-called literary words considered suitable to a work of art do occur in the text. See, for example, aksami 'forgiveness' (instead of pangapunten), jaladri 'sea' (instead of segara), lalis or palastra 'to die' (instead of mati), or sinung 'given' (instead of diwènèhi); these are distributed throughout the text. Another sign of embellishment is the tendency to employ variation by using synonyms. The idea of "inner feelings" or "mood", for example, which occurs six times, is expressed each time by a different word: by kalbu, driya, ati, tyas, ambek and 
once more ambek, but in its shortened form bek. Other words are varied, but not always. Technical words such as praja 'district' or 'country', bupati (spelt bopati) 'regent' and Cina 'Chinese' appear without variation.

This sober style, with little or no embellishment, is known in rhetoric as the "low style", as distinct from the middle and high styles. Its aim is to inform and to persuade with arguments based on reason, contrary to the two other styles which are meant to entertain or to urge to take action and consequently require the means to move (Braet [N.d.]: 121).

These are just a few examples to show how rhetoric helped to shape the Sajarah Cina. To conclude this section, I would like to draw attention to one example in which rhetoric is sacrificed, it seems, to political considerations. The rules of prosody used in the Sajarah Cina prescribe a fixed final vowel for each of the six lines of a stanza. Line 8e contains a mistake: it has final $u$ instead of the required $a$, in kautunganipun 'profit of (the Dutch government)':

\author{
pira ta kautunganipun how much is not the profit \\ gupermèn makethi-kethi of the government, hundreds of thousands!
}

The mistake could easily have been avoided by writing kautunganira, with the same meaning. However, -ira has a honorific connotation, which might not have been considered fitting in this particular context, while the author could also not have made his statement - a political stance expressed in one letter!

\title{
CONCLUSION
}

The nineteenth-century poem Sajarah Cina is preserved in a unique manuscript most likely meant for private use. Nothing is known about the background of the text or the author, Apdul Mutalip. In this article it is proposed to interpret the Sajarah Cina as an apology, aiming to redress the negative image of and bad feelings current in the nineteenth century towards the Chinese population of Java - a problem as sensitive then as it is now. The poet offers many arguments to support his alternative view, which he presents in an elegant and skilful way while stressing how the Chinese have contributed to the prosperity of the Javanese and are an integral part of Javanese society. In doing so, he is helped by a rhetoric amazingly similar to the Western rhetorical tradition. However, this does not mean that Javanese rhetoric is indebted to the Western tradition, either directly or indirectly. The Javanese tradition existed long before the first appearance of the Europeans, over a period of one thousand years or more: the same principles of rhetoric adhered to in the Sajarah Cina of the nineteenth century were applied in the Old Javanese Ramayana of the ninth century. Other possible sources like India or China are to be excluded on the grounds that the art of rhetoric in the literatures of those countries did not develop along the lines discussed here. We cannot but conclude that its rhetorical tradition is an independent achievement of Javanese literature. 


\section{REFERENCES}

Braet, Aontoine. [N.d.]. Retorische kritiek; Overtuigingskracht van Cicero tot Balkenende. Den Haag: Sdu.

Bruineman, J.A.M. 1946. “De invloed der Chineezen”, in: C.W. Wormser (ed.), Wat Indië ontving en schonk, pp. 56-76. Amsterdam: Wereldbibliotheek.

Corbett, Edward P.J. and Robert J. Connors. 1999. Classical rhetoric for the modern student. Fourth edition. New York/Oxford: Oxford University Press. [First edition 1965.]

Kennedy, George A. 1998. Comparative rhetoric; An historical and cross-cultural introduction. New York/Oxford: Oxford University Press.

Molen, Willem van der. 2003. "A token of my longing; A rhetorical analysis of Sita's letter to Rama, Old Javanese Ramayana 11.22-32", Indonesia and the Malay World 91: 339-355.

Molen, Willem van der. 2015. "Documents on the life of Ko Ho Sing (18251900)", in: Teresa Liliana Wargasetia (ed.), Proceeding; The 2nd International Conference on Chinese Indonesian Studies, pp. 224-233. Bandung: Maranatha University Press.

Pigeaud, Theodore G.Th. 1980. Literature of Java; Catalogue raisonné of Javanese manuscripts in the library of the University of Leiden and other public collections in the Netherlands. Vol. 4: Supplement. The Hague: Nijhoff. [Bibliotheca Universitatis Leidensis Codices Manuscripti 20.]

Ricklefs, M.C. 2008. A history of modern Indonesia since c. 1200. Fourth edition. Basingstoke: Palgrave Macmillan. [First editon 1981.] 
APPENDIX 1

Photographs of the Sajarah Cina (reduced size).

Source: Leiden University Library Manuscript KITLV Or 409.

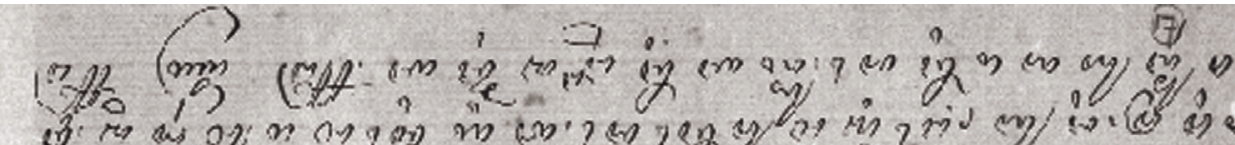

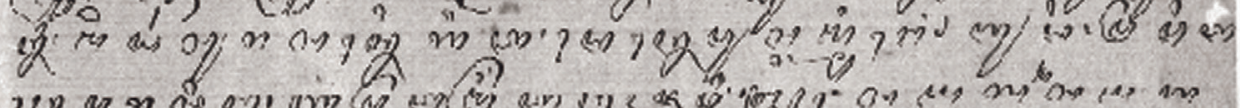

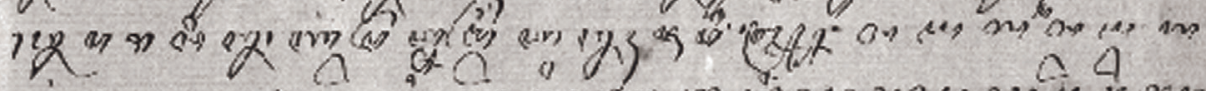

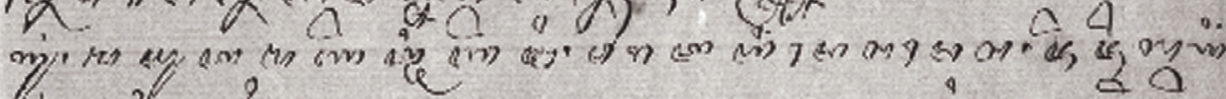

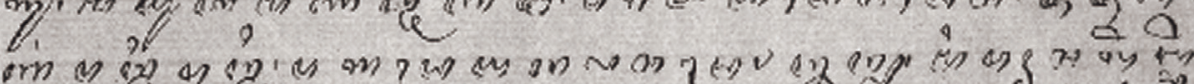

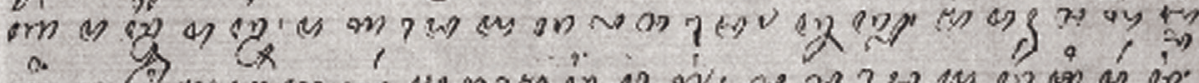

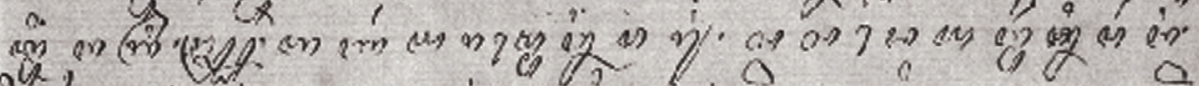

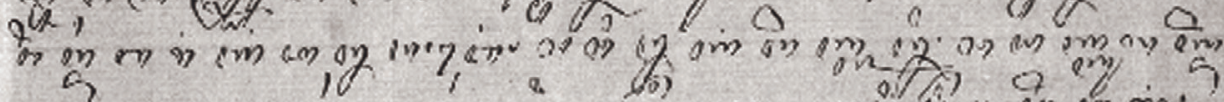

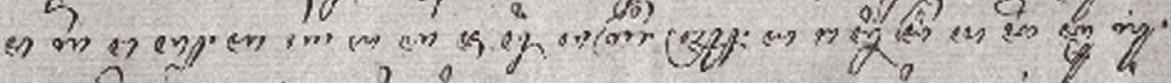

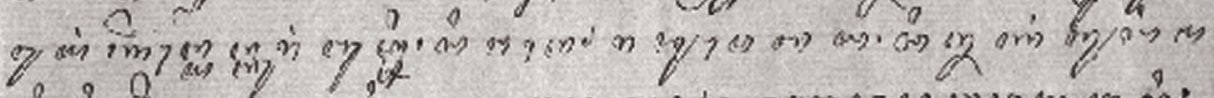

के

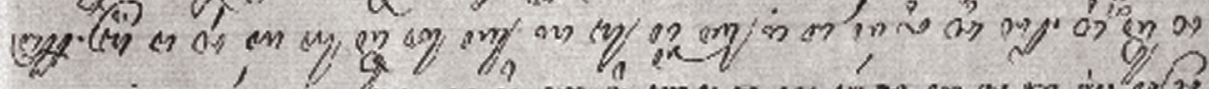

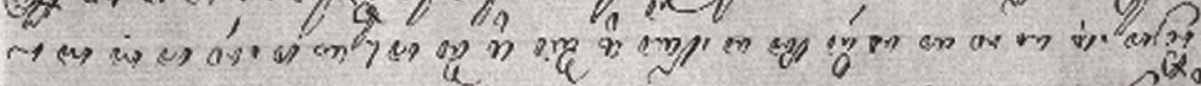

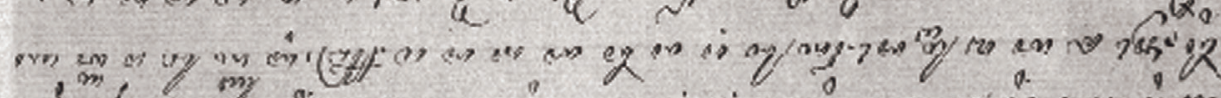

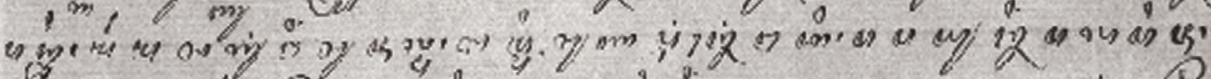

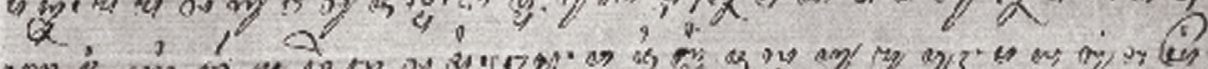

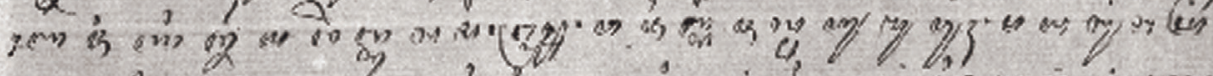

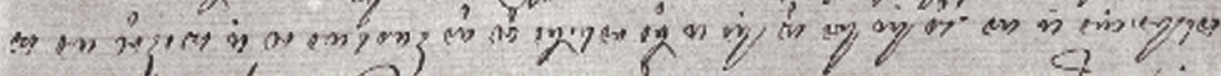

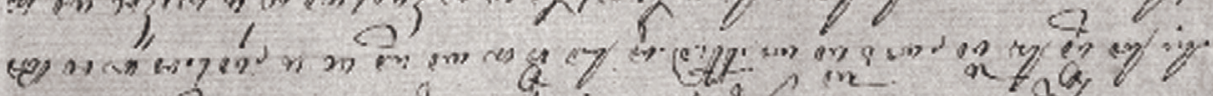

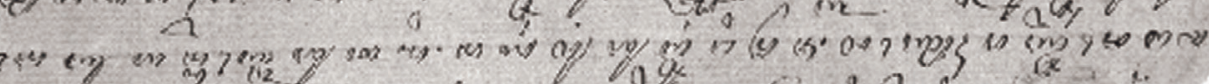

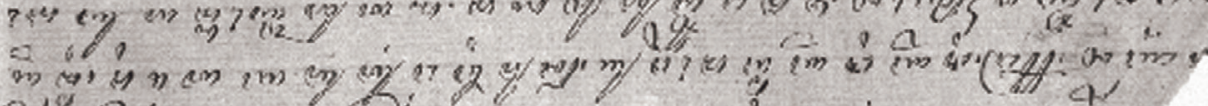

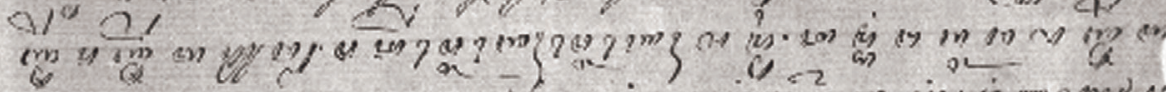

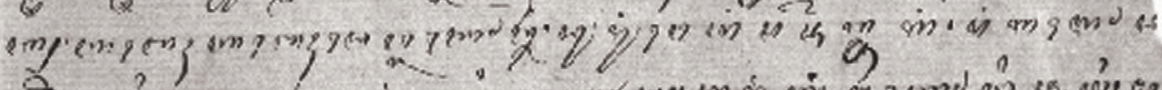

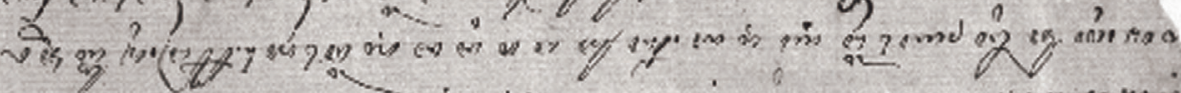

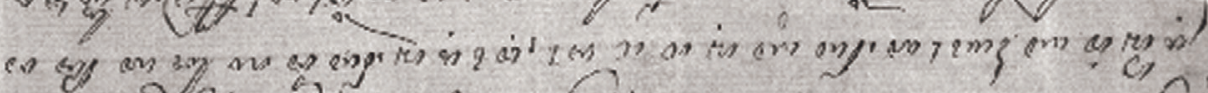

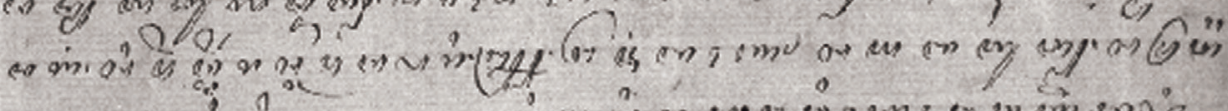

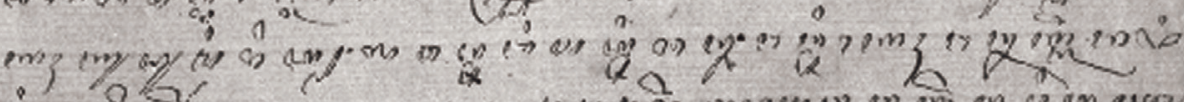

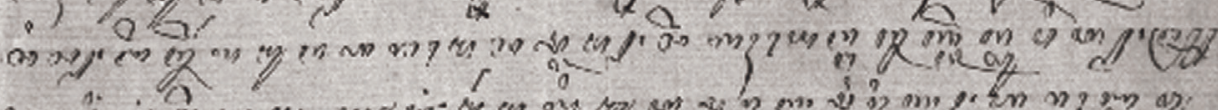

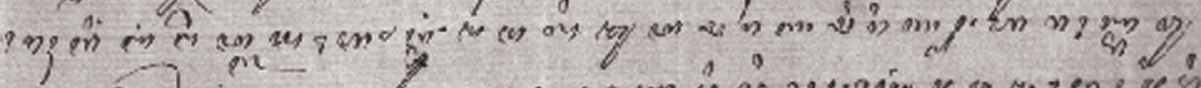

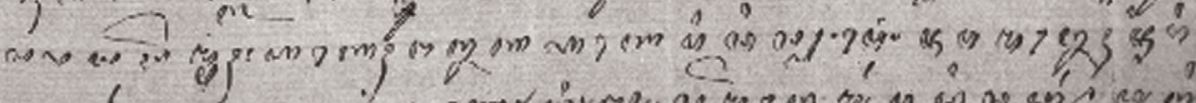

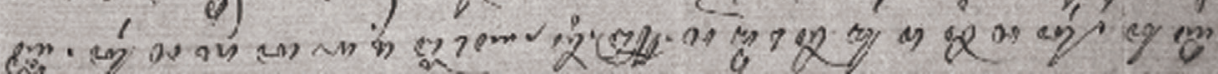




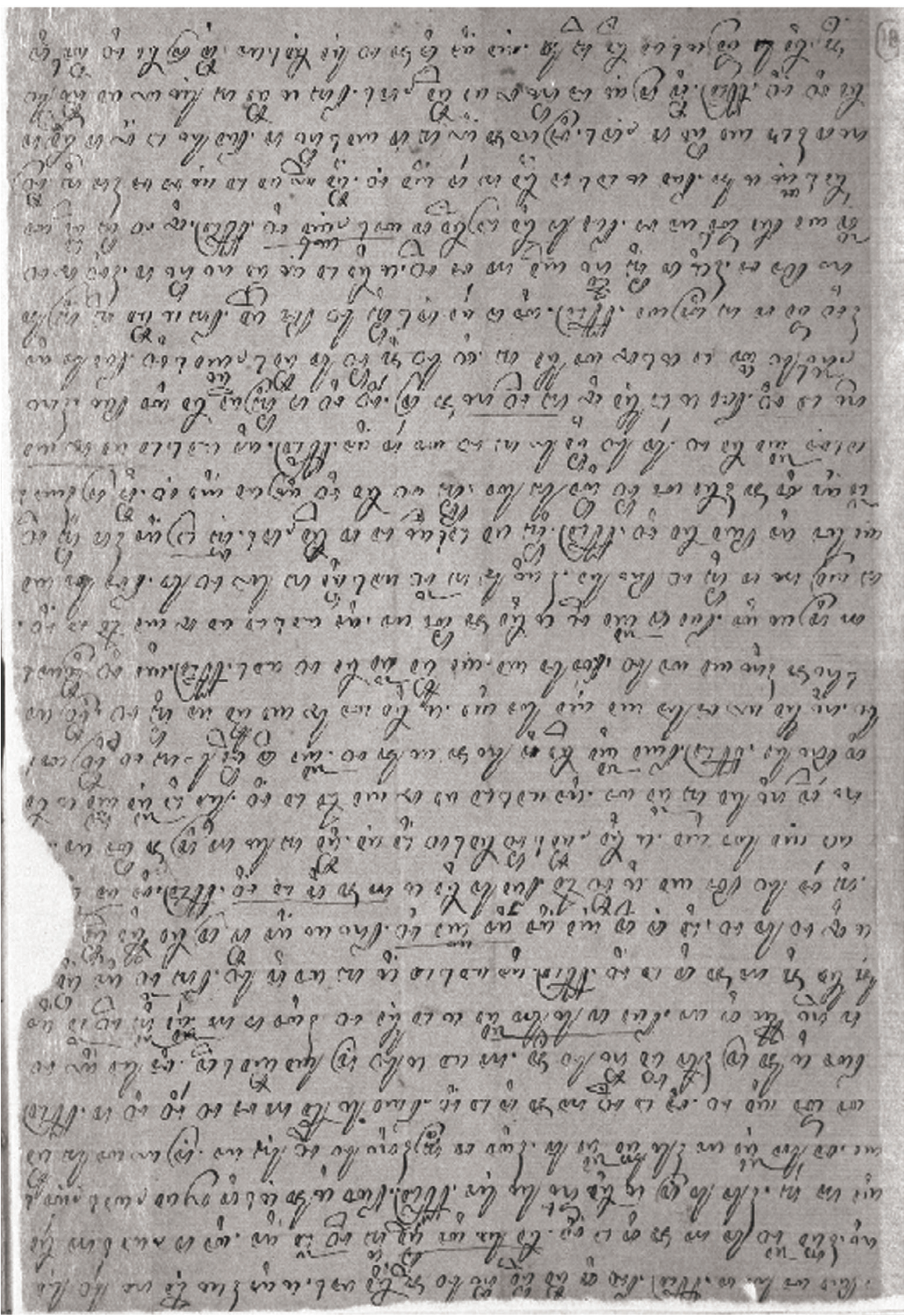




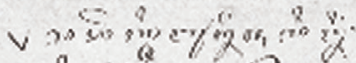

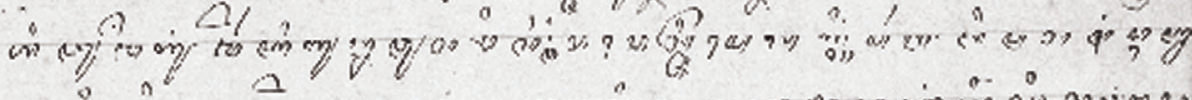

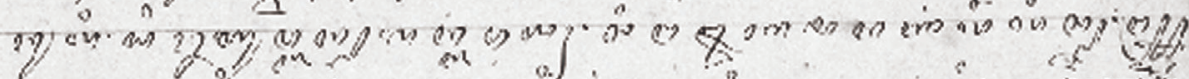

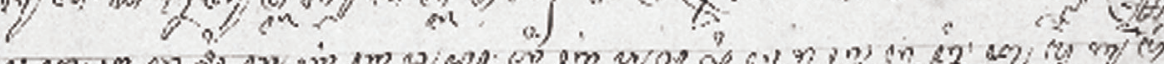

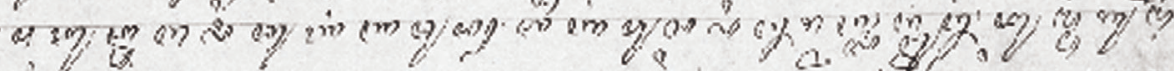

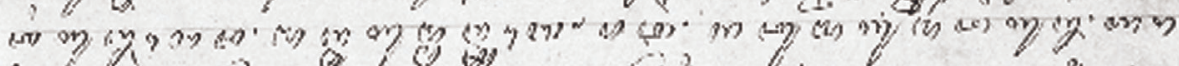

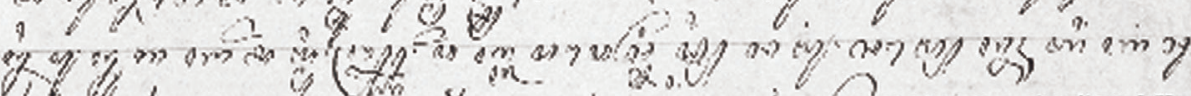

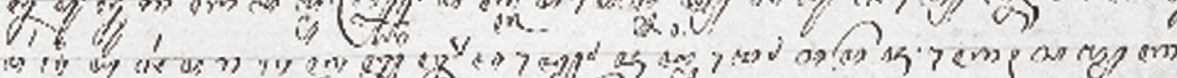

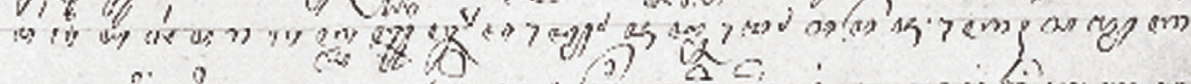

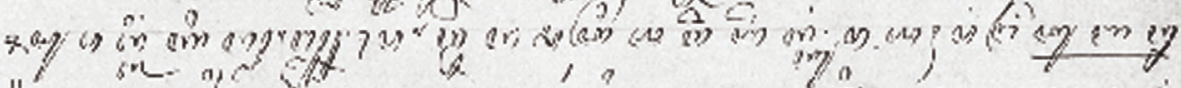

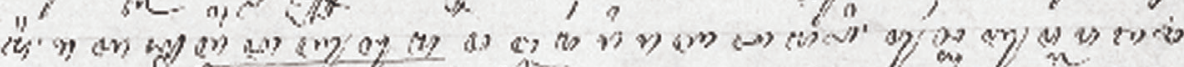

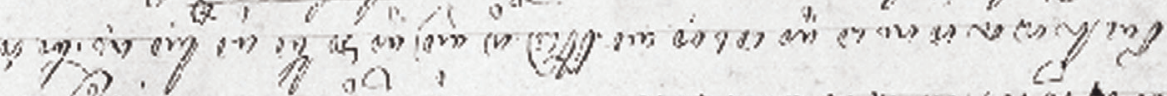

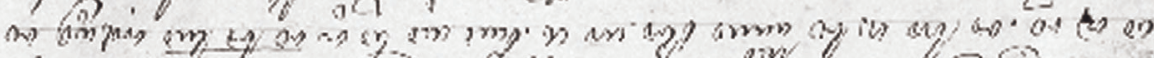
9 .

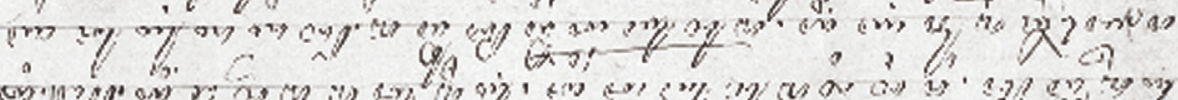

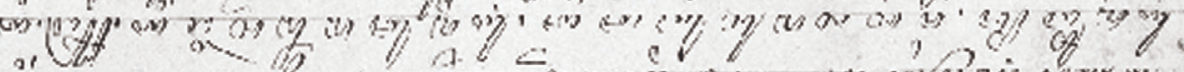

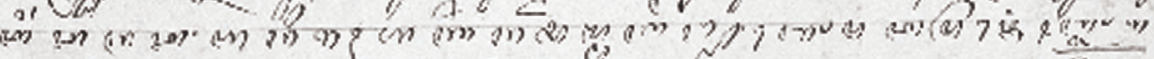

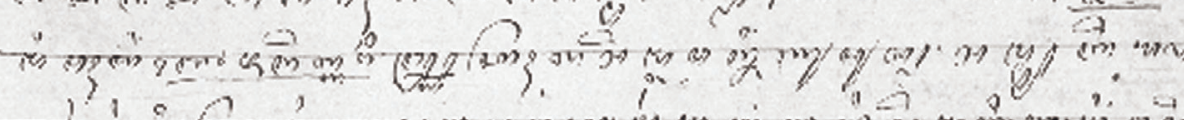

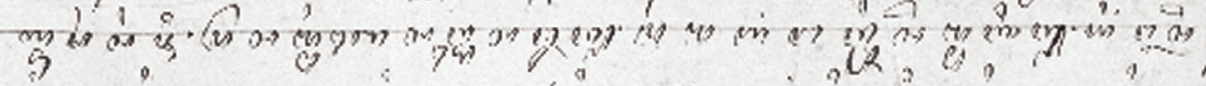

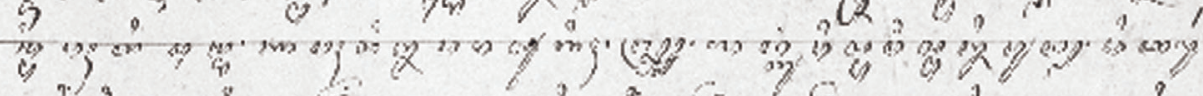

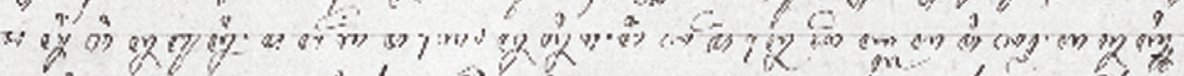

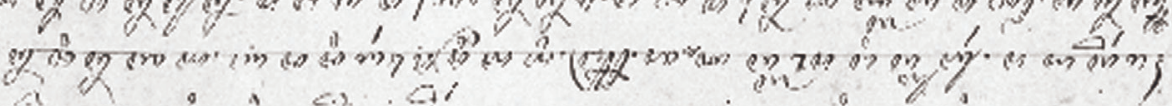

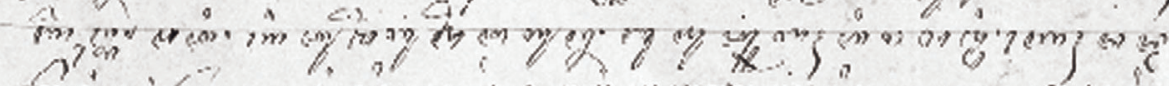

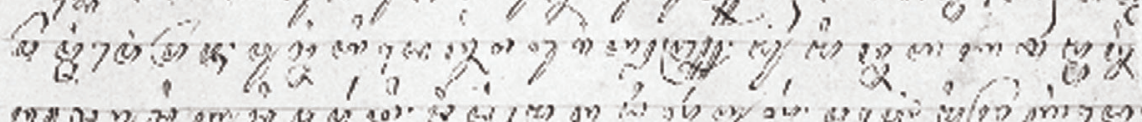

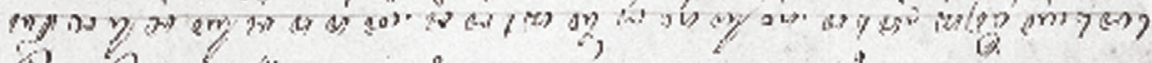

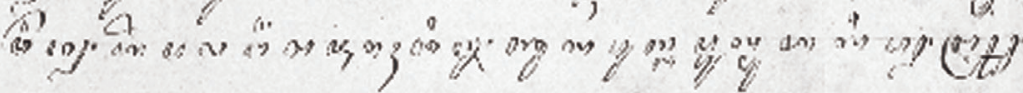




\section{ApPENDIX 2}

\section{Text and translation of the Sajarah Cina ${ }^{1}$}

1

\author{
/p. 17/Kanthi ma<nga>ngen ing kalbu \\ dénira mayun murwani \\ medhar surasaning gita \\ déné wus lami ngong udi \\ prawitané para Cina \\ kang prataming tanah Jawi.
}

2

$$
\begin{aligned}
& \text { Saya la<ma> saya agung } \\
& \text { mayuta makethi-kethi } \\
& \text { warata ing désa-désa } \\
& \text { jejel ingkang panti-panti } \\
& \text { pagadhéyan pacadonan } \\
& \text { miwah salebeting nagri. }
\end{aligned}
$$

$$
\begin{aligned}
& \text { Akarya raméning warung } \\
& \text { sesadéyan war[s]<n }>\mathrm{i} \text {-warni } \\
& \text { ngendi barang kang tan ana } \\
& \text { bangsa Cina kang nekani } \\
& \text { cadhak kulak dedagangan } \\
& \text { akarya arjaning nagri. }
\end{aligned}
$$

Dhanganing driya tetulung nguyangken yèn kurang buti

singa nora duwé badha Cina kang nuli maiti senadya kanthi anakan nora kèh dénya mèt bathi.

$5 \quad$ Mring pasar ayun tetuku lamun kakurangan picis $\mathrm{Ci}<$ na $>[\mathrm{n}]<$ w $>$ us padha dhedhasar pagadhèn tharik-tharik nadyan warnaa sabarang wastra katga pacul kudhi.
Compelled by a strong desire

I wish to write a poem and make its contents known. Because for many years I have made special study of the early history of the Chinese, the first of their kind to come to Java.

Their numbers are increasing all the time, hundreds of thousands, millions. They spread all over the countryside; it is crowded with their houses, pawnshops and opium dens. It is the same in the towns.

They make the place bustle with shops selling all sorts of wares. Whatever is not there the Chinese will find it. Their small business credit system causes the country to thrive.

They are delighted to help those who sell their crop in advance when they are short of food.

If a person does not have capital, the Chinese will lend money, albeit with interest, but they profit little by it.

On one's way to the market to shop, if a person is short of money, the Chinese are there with their stalls, pawnshops in neat rows. No matter what the object might be, clothes, krisses, hoes, grass-cutting knives,

1 Source: Manuscript KITLV Or 409. The spelling of the Javanese text has been normalized, the stanzas have been numbered. The following symbols are used:
$<>$
[] added by the scribe of the manuscript.
italics omitted by the scribe of the manuscript.
... reading suggested by the present author.
underscore illegible or unintelligible. underscore in the manuscript. 
6 Sedaya tan ana wangsul dè $<\mathrm{n}>$ rumat sajroning panti marma sagunging sujalma sami suka-renèng ati pepayuning palawija béjing kinarya nebusi.

$7 \quad$ Wajibing jalma tumuwuh padha sunga trima kasih marang sakabèhing Cina dénira gung mitulungi arang kang duwé tyas arda norana bek sapta budi.

8 Tan katon lamun tetulung yeku ambeké utami malar sung untunging praja sakyèh pakter dèn sagemi pira ta kautunganipun Gupermèn makethi-kethi.

9 Sangking pakter-pakter apyun pater plèkèh-plèkèh sami tambangan lan pakter $a . . . k$ kabèh-kabèh dèn lakoni durung ngétang pajeg dagang panggaot... pajeg bumi.

10 Yèn lélang dadi pangayun arang kang nglakoni juti

ma ... dadya tetuladan marang wong désa samangkin akèh karem marang dagang sipen beras lawan pari.

11 Ngrajang bako saya baut tobacco.

sapratingkah kudu mirit

lawan tabiyating Cana

nganti kèh nganakken picis scale.

bener lamun agamèslam cenggah yèn nganakken dhuwit. nothing is rejected;

everything is stored in the warehouse.

So everybody

is happy and feels satisfied.

The good yields of the second crop will be used to buy back one's possessions.

Every human being ought to be grateful to all Chinese

for their never-failing help.

Greed is a rare trait,

Among them are no sapta budi.

No one sees it when they are helping.

That is their great virtue.

Even the state benefits from them.

All the tax-farms they take on:

how much is not the profit

of the Government, hundreds of

thousands!

from the opium farms,

the slaughter-houses,

the ferries, the excise duties on spirits,

that are all imposed,

not yet counting the tax on trade,

crafts, land.

When an auction is imminent, rarely are there people who play dirty tricks.

... to be even more an example

for the villagers.

Many are fond of trading,

storing rice at various stages.

They are becoming increasingly skilled in slicing

In every activity they feel an urge to imitate.

And the nature of the Chinese

includes lending money at interest on a broad

It is true that Islam

opposes interest. 
Rèhning banget kaya ontung marma limut sarak sirik

Arabé wus padha nemah akèh nganakaké picis wong Jawa manèh nyirika

tur salat arang nglakoni.

13 Samené murwani catur duk wi/p. 18/ wit<é> Cina prapti anèng nungsa Jawi ingkang jumeneng naréndra nguni jeng Sultan Agung Mantaram

wonten palwa dagang prapti

14 Sing Cina pan rep ing alun

palwa kérem ing jaladri wong palwa kathah palastra miwah dedagangan enting sangking parmaning Pangéran juragané tan ngemasi.

15 Cik $\mathrm{G}<\mathrm{o}>$ ng Té panengranipun dahat $\mathrm{d}<$ é>nya kawlas asih palwa lan daganganira sedaya kelem ing warih dadya laju mring Mentaram nedya sumiwèng narpati.

16 Katrima pan dasihipun Cik Gon Té wus majing suci manut sarèngat rasulolah

gya tinanem mring Pasisir praja Lasem sinung ngaran Singaleksana ngabèi.

17 Ing warta sampun misuwur sanak kadangé kèh prapti sangking nagri Cina samya tumut wisma tanah Jawi ing Lasem miwah ing Rembang wonte pengagengé nami.
As it brings excess riches and profit, which causes neglect of the law and crime.

The Arabs have resigned themselves; many lend money at interest. Why should the Javanese feel abhorrence if only the prayer they rarely perform.

Now I am going to say something about the time the Chinese first arrived in the island of Java. The ruler in those days was His Highness Sultan Agung of Mataram.

Then a trading vessel was arriving

from China. Suddenly it was caught up by huge waves and foundered at sea.

Many of the people on board perished and the cargo was completely lost. Thanks to the grace of the Lord the master did not die.

His name was Cik $G<0>n g$ Té.

He was in a pitiful state;

his ship and his goods, all had sunk beneath the waves.

So he went to Mataram intending to offer his offices to the king.

He was accepted as a servant.

Cik Gong Té converted to Islam and became a follower of the law of the Prophet of God.

Then he was posted in the Pasisir, to the district of Lasem, and the name Ngabèi Singaleksana was bestowed on him.

When the news spread, many of his relatives began to come from China, who also settled in Java, in Lasem and in Rembang. There was a famous big shot, 
Cina kyai tukang kasud wus umanjing Ėslam sugih nulya sami pa $<$ la $>$ krama Singaleksana ngabèi atmajanira sekawan tiga priya èstri siki.

Bésanan lan tukang kasud

suta kalih jalu èstri

sami antuk sutanira

ki tukang kadud anuli sutèstri sampun weweka sajuga jalu pinekik.

20 Nulya pinarakan kang ibu Singaleksana ngabèi tan lama nuli perla... atmaja priya gumanti nanging sanès mantonira ki tukang ka... kang dadi

21 Singawijaya ranipun lestari kadya sudarmi ...nten Cina prapti inggal Cik Go Hi... ingkang wewangi sawusira ...njing Islam suwita maring ngabèi.

$22 \quad$ Singawijaya jinujung ing Lasem kin[k]arya patih sanung ngaran Kayuruwan awig ca lepas ing budi wektéku prang Surabaya jeng sultan dhaw[u]ah prajurit.

23 Pasisir sadaya ngluruk Singawijaya sengading sakit datan tumut aprang

amung sesulih mring patih pun Kanyuruhan kang yuda katongton prawirèng jurit.
A Chinese, a kyai, a burlap-seller, who had embraced Islam, a rich man. He now decided to arrange marriages with Ngabèi Singaleksana, who had four children, three boys and one girl.

He and the burlap-seller established family ties, two of his children, a boy and a girl, married the other's children.

Thereafter, the burlap-seller's daughter had a child, one, a beautiful boy.

Then the mother was ...

Not long after that

Ngabèi Singalaksana passed away. He was succeeded by his son, but it was not the son-in-law of the burlap-seller who became his successor.

Singawijaya was his name He followed in the footsteps of the deceased.

Another Chinese arrived, Cik Ga Hi... by name.

After he had embraced Islam he entered into the service of the ngabèi.

Singawijaya was raised to the position of patih in Lasem and was given the name Kayuruwan. He was skilled, ..., clever.

At that time the war with Surabaya raged.

His Highness the Sultan called up his soldiers.

The entire Pasisir went to war.

Singawijaya pretended to be ill and did not go to war with the others.

He only sent a surrogate for himself, one Kanyuruhan who fought.

He appeared to be brave in battle. 
Unggul d<é>nira prang pupuh marma kinarya bopati ing Lasem ran Mertiguna Singawijaya wus kandhah linungsur lelenggahira déning jeng sultan Mentawis.

Wau ta kya/p. 19/ i tumenggung Mertiguna wus sesi<wi> pawèstri pélag ing warna diwasa sang retna nuli dhinaupken lan kang wayah Singaleksana kang l[i]alis.

26 Patutan sing tukang kadud ingkang wus pinarakan nguni tumenggu Mertiguna séda mantu gumantya bopati

na tumenggung Mertiguna aranipun Ugaksemi.

Weka pawèstri dhyi namung samyéndah ingkang suwarni dhasar paranakan Cina

<sayekti kuning jakining>

dadyojatting mocapraja

kèh samya kadh[é]uwan kingkin.

28 Wonten satriya nehen kung wayah pangrang Tuban nami

rahadyan Tirtakusuma panglamarira katampi wus dhaup lawan sang retna langkung binuja ing krami.

29 Kadangé ingalap sampun satriyèng Kudus pinekik rahadyan Kusumayuda semana ki tugung lalis. mantu dyan Tirtakusuma ingkang jumeneng bopati.
The way he fought was excellent. Therefore, he was made regent in Lasem, with the name Mertiguna. Singawijaya was degraded and discharged from his office by His Highness the Sultan of Mataram.

Kyai tumenggung Mertiguna had a child, a girl, good-looking. Once grown up the girl was married to the grandchild of the late Singaleksana,

through the burlap-seller's daughter who had been ... at the time.

Tumenggung Mertiguna passed away. His son-in-law succeeded him as a regent.

... Tumenggung Mertiguna.

His name was Ugaksemi.

He had only daughters, all good-looking.

After all, they were Chinese of mixed blood.

They had a really golden complexion and were pretty.

There names were on everybody's lips in the Outer Provinces.

Many ... by lovesickness.

There was a nobleman ... love.

He was a grandson of the Lord of Tuban called

Radèn Tirtakusuma.

His proposal was accepted.

He married the girl

at a big ceremony.

Her elder sister had been taken already by a handsome nobleman from Kudus, radèn Kusumayuda.

When the tumenggung passed away, his son-in-law, dèn Tirtakusuma, became regent 
$30 \quad$ Ing Lasem nama tumenggung

Tirtakusuma sesiwi

dyan tumenggung Tirtanata

anerahaken semakin

bopati prajèng Blora

miwah ing Bojanegari.

Trah Lasem lawan ing Kudus samya kempal dadi siji prasami bésan-b<é>sanan marma anganti semakin ing Lasem miwah ing Rembang kathah Cina para sugih.

32 Lan gung wisma-wismanipun wit purwaning Cina nguni pangageng pagonanira nging samené teka awis anak Cina-Cina kaya kang dadi garwèng priyayi.

$33 \mathrm{~A}<\mathrm{pa}>\tan$ kapéngin luhur padha nerahken $\mathrm{b}<\mathrm{O}>$ pati ki tumenggung $<$ M $>$ ertaguna buyut canggahira sami

kèh dad... praptiwèng praja wus titi déniragurit.

34 Mung minta aksamini...n., saru-sikuning wewarti

dedimèn dadi lar-ular pawong mintra kang dé wrin tepanging sajarah Cina

kula pun Apdul Mutalip. in Lasem with the name Tumenggung Tirtakusuma. He had a son, Dèn Tumenggung Tirtanata, who became the ancestor of the present regents of Blora and Bojanegari.

The houses of Lasem and Kudus united, becoming one through intermarriages. That is why even today in Lasem and Rembang there are so many Chinese who are rich

and have big houses.

It began with the Chinese in the past occupying prominent positions.

But now one rarely sees children of rich Chinese who become the wives of high officials.

Are they not interested in high status, in begetting regents?

As for Ki Tumenggung $<\mathrm{M}>$ ertaguna, of his great-grandchildren and greatgreat-grandchildren many did reach the courts.

Finished is my composition of a poem.

I only ask forgiveness for the mistakes and shortcomings in my story.

May it serve as an introduction for my friends, who ought to know the parts of Chinese history so close to them.

Your servant, Apdul Mutalip. 
Annotations to the text and translation of the Sajarah Cina

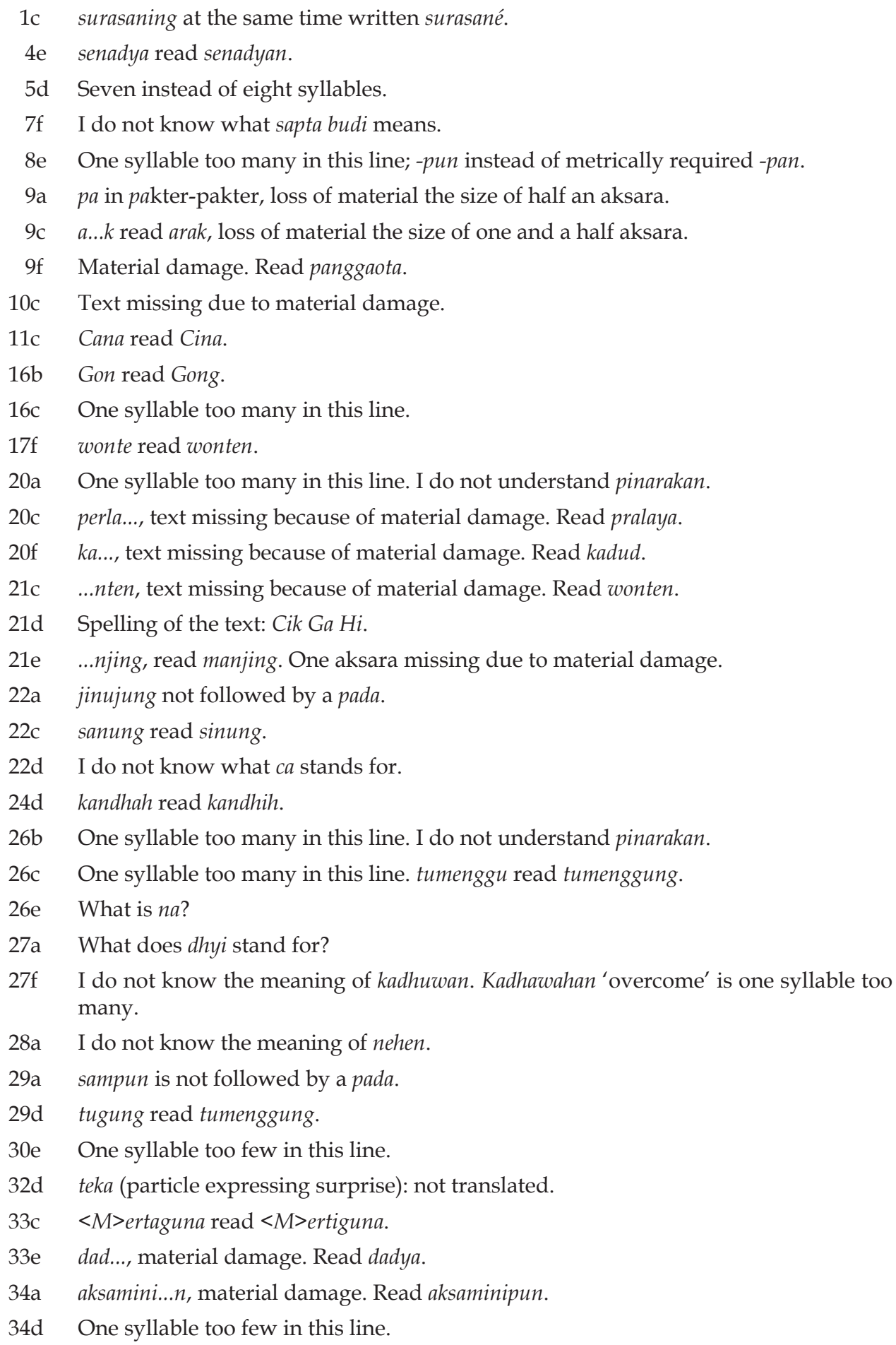

